\title{
Provincial Income Inequality and Spatial Autocorrelation Across Turkish Provinces: 1992-2013
}

Çağrı Levent USLU (http://orcid.org/0000-0001-7651-8779), Department of Economics, Yeditepe University, Turkey; e-mail: cluslu@yeditepe.edu.tr

\section{Türkiye'de İl Bazında Milli Geliş Eşitsizliği ve İller Arası Coğrafi Otokorelasyon: 1992-2013²}

\begin{abstract}
The aim of this paper is to investigate provincial income inequality, the degree of spatial autocorrelation between provinces in Turkey and to determine whether low and high income provinces are randomly distributed or not. Gini Results indicate that coefficients are increasing throughout the period, and regional income inequality is increasing over time. The difference between the Weighted and Unweighted Gini coefficients reveals that the level of inequality further increases when population shares of provinces are taken into consideration. Spatial autocorrelation results indicate that there is a strong spatial autocorrelation between provinces. Low (high) income provinces are mostly surrounded by low (high) income provinces. Results also indicate a tentative border between the high income west and poor income east provinces. This border moves even further west throughout the period under question. This fact may be interpreted as further concentration of richness at the western provinces.

Keywords $\quad$ : Regional Income Distribution, Regional Income Inequality, Regional Gini Index, Spatial Autocorrelation.

JEL Classification Codes : O18, O11, D63.

Öz

Bu çalışmanın amacı il bazında gelir eşitsizli ve iller arasında mekânsal otokorelasyonu, zengin ve fakir illerin dağılımının tesadüfi ya da bir şablon takip edip etmediğini incelemektir. Gini sonuçları incelenen dönem boyunca artış göstermektedir ki bu da gelir eşitsizliğinin artığına işarettir. Gini ile illerin nüfuslarının da dikkate alındığı Ağırlıklı Gini sonuçları kıyaslandığında gelir eşitsizliğinin daha da arttığı görülmektedir. Mekânsal otokorelasyon sonuçları iller arasında kayda değer seviyede
\end{abstract}

1 This article is the revised and extended version of the paper presented in "Third International Annual Meeting of Sosyoekonomi Society" which was held by Sosyoekonomi Society and CMEE - Center for Market Economics and Entrepreneurship of Hacettepe University, in Ankara/Turkey, on April 28-29, 2017.

2 Bu makale Sosyoekonomi Derneği ile Hacettepe Üniversitesi Piyasa Ekonomisini ve Girişimciliği Geliştirme Merkezi tarafindan Ankara'da, 28-29 Nisan 2017 tarihlerinde düzenlenen "Üçüncü Uluslararası Sosyoekonomi Derneği Yıllık Buluşması"nda sunulan çalışmanın gözden geçirilmiş ve genişletilmiş halidir. 
otokorelasyon olduğunu ortaya koymaktadır. Fakir (zengin) iller çoğunluklar diğer fakir (zengin) iller ile çevrelenmiştir. Bir diğer önemli sonuç ise, batılı zengin iller ile doğudaki fakir iller arasında çizilebilecek farazi bir sınırın olduğu ve bu sınırın zaman içerisinde daha batıya kaydığıdır. Bu durum ülkedeki zenginliğin zaman içerisinde battı illerinde konsantre olduğu şeklinde yorumlanabilir.

\section{Anahtar Sözcükler $\quad$ : Bölgesel Gelir Dağılımı, Bölgesel Gelir Eşitsizliği, Bölgesel Gini} Endeksi, Mekânsal Otokorelasyon.

\section{Introduction}

The source and evolution of income inequality and counter policies to reduce it are some of the main issues of economics. What is understood by "income inequality" is generally the inequality between different income groups. Yet, recently, the income inequality also refers to income differences between genders, ethnic groups, education levels. In this regard, especially after the World War II, income inequality between countries or regions of a particular country started to gain importance.

The main reason of regional income inequality is the concentration of economic activities in some particular regions of the country. This problem concerns a wide variety of countries, ranging from the most developed countries like the U.S., Germany and Japan to developing countries like Brazil, Poland and Turkey. The geographic size of the country does not matter either; both large countries like China, Russia and small countries like Luxembourg, Belgium suffer from regional income inequalities.

In the Turkish case, especially after 1980, the increase in economic integration with the western economies led to an increase in the strategic importance of Turkey in the global arena and ultimately has caused an economic transformation within the regions of Turkey. Only some particular sectors, labor force and some particular lifestyles could survive in this process. In this regard, during this process, some regions of Turkey have been kept away from economic growth. This implicit enforcement further increased the poverty in externalized regions. Rich regions increased their richness by using the resources (especially labor and capital) of the poor regions and this vicious circle prevented the poor regions to encounter high growth rates.

Studies on regional income and migration indicate that the income inequality between regions of Turkey has increased after adoption of liberal policies in the early 1980's. Though there are earlier studies on this issue, convergence as a policy item is a new addition to the development agenda. The State Planning Organization (SPO) (and recently Ministry of Development) has defined the socio-economic development levels of provinces in 1981, 1985, 1991, 1996 and 2003, and the conclusions of these reports are similar, indicating that the economic duality between the east and the west of Turkey is becoming more apparent year after year.

There is a considerable amount of literature devoted to the theory and application to reduce regional income inequality. One may easily categorize the literature into two 
opposing arguments. Some argue that poor regions grow faster than rich regions in terms of Gross Domestic Product (GDP) per capita. According to this theory, the initial period per capita income level and per capita income growth rate are inversely related. The high initial income level leads to low growth rates and the low initial income level leads to high growth rates. Therefore, when a comparison between two economies with some unequal levels of initial per capita income is made, the growth rates will favor the poor, which turns out to decrease the degree of regional income inequality. On the other hand, some believe that poor regions are externalized as the level of liberalization and globalization increases, and these externalized regions will be worsened in terms of unemployment, living standards and economic growth. Thus, struggling with regional income inequality needs some counter measures.

There are two motives of this study; (a) to determine level of inequality at the provincial level, (b) to determine the spatial autocorrelation and envisage the evolution of income clusters in Turkey. The second part of the study is devoted to a brief literature review. In the third part, data and methodology are discussed. The fourth part is devoted to findings and the last part includes conclusion.

\section{Literature Review}

The regional income inequality may be regarded as sub-discipline of income distribution and inequality; therefore, the techniques in measuring the regional income inequality were adopted from the theory of income distribution and inequality. While the theory of income distribution deals with the incomes of factors of production like labor and capital, the regional income distribution deals with the distribution of income among regions of a country. An introduction to the income distribution theory would be useful in understanding the evolution of regional income distribution theory.

The distribution of income between households is known as the "distribution of income". The "functional income distribution", on the other hand, refers to the distribution of income among factors of production. For both definitions, there are two main questions to be answered; (i) why are some people rich and others poor, (ii) whether the observed distribution of income can be considered to be satisfactory in terms of economic and social welfare? A wide variety of economists, including Adam Smith, Karl Marx, John Maynard Keynes, have dealt with the possible answers to these questions for more than 250 years.

The neo-classical approach to the problem was formulated in the last quarter of 19th century and is known as "marginal productivity theory of distribution". According to this theory the income of a particular input is determined by marginal product of that input. This way of theorizing income distribution did not solve the problem but instead further increased the debate on this issue. While this debate on distribution of income between individuals occupied economists, a new aspect of the problem aroused after the Second World War. The distribution of income between nations became as important as the distribution of income between individuals (DeJuan \& Tomljanovich, 2005). When the focus of income distribution shifted to the national level, two opposing thoughts have emerged. 
On one side, some authors argued that post-war developments in the world economy, are irreversible and they are beneficial for the poor economies (e.g. Kuznets (1955), Barro \& Sala-i Martin (1992). Specifically the dynamics of economic development and globalization will ultimately ensure high growth rates in poor nations and the income level of these poor nations will approach to those of the rich nations. This way of thinking has enabled the so called "income convergence theory".

However, on the other side, some argued that, globalization increases unemployment rates and decreases economic growths in poor countries and, thus, increases the income inequality between nations (Rodrik (1997), Falk (1999), Dinler (2005)). In other words, the natural forces of globalization lead to divergence rather than convergence in incomes.

The debate on costs and benefits of globalization is increasing year after year. The importance of this debate for the regional level is that the shift in focus of income distribution theory from individual level to national level accelerated the number of studies focusing on inequalities between regions of a particular country. While originally it dealt with income inequalities between income groups, Kuznets' 1955 presidential address to the American Economic Association may be regarded as the starting point of regional income convergence theory. The idea underlying Kuznets arguments became the backbone of regional income convergence theory which simply argues that at the first stages of economic growth, inequalities between income groups will increase, but then after a turning point, these inequalities will start to disappear.

At this point we should focus on empirical studies investigating the convergence between regions of a country and especially on those between provinces in Turkey. We may infer that if there exists a convergence between provincial incomes, the Gini coefficient will decrease and the income clusters will vanish. The research of Erk, Ateş, and Direkçi (2000) deserve mentioning. Erk et al. have argued that successively constructed convergence attempts have their own biases due to neglected explanatory variables like economic and social factors. In order to catch the real convergence (divergence) patterns, additional explanatory variables like human capital and physical capital should be included in the model. Conditional convergence results of Erk et al. are in contrast with other studies on Turkey. Authors found that if Marmara region is excluded there is evidence of regional income convergence among geographic regions of Turkey.

Karaca (2004) approached the regional income inequalities from another perspective and investigated whether Priority Provinces in Development (PPDs) are converging or diverging with the rest of the provinces. PPD policy started in 1968 with 22 provinces. The number gradually increased and reached 36 provinces by 2004 . The paper analyzes 25 years between 1975 and 2000. The convergence indicator indicated divergence, only 1980-1990 sub-period. In the same study, the author also calculated the standard deviation of per capita income and found that an increase from 0.4243 to 0.5778 in between 1975 and 2000. Karaca (2004) concludes that government policy aiming to decrease regional income inequalities did not result in its desired goal. 
Öztürk (2005) employed three different regional income inequality measures; namely the Gini, Atkinson and Theil indexes for the period 1965-2001. According to Öztürk, the level of inequality indicators shows an increasing trend between 1975 and 1987. After 1987, however, these indicators show a decreasing level of income inequality among regions. Öztürk argues that figures in Turkey verifies Kuznets' inverted U curve hypothesis where the peak point for Turkish economy is 1987.

Empirical studies on income distribution, with little exception, reveal that there is no evidence of a strict convergence among provinces or regions. The common idea in regional income literature (Akgüngör (2003), Öztürk (2005), Karaca (2004), Erk, Ateş, \& Direkçi (2000), Başlevent and Dayığlu (2005)) is that there might be three possible reasons for diverging regions in Turkey: (1) Turkey has not completed its development process so that inter-sectoral productivity differences remain, (2) the macro-economic environment and macro-economic policies have had different impacts on regions and/or (3) government policies geared toward closing income gap has been unfruitful.

\section{Data and Model}

\subsection{Data}

This study employs provincial Per-Capita GDP data. There are two practical problems regarding the data: (a) number of provinces has increased from 67 to 81 between 1989 and 2001, (b) official statistics released by Turkish Statistical Institute (TURKSTAT) covers the period between 1987 and 2001, and from 2001 onwards, no official statistics are released.

The first problem may have been solved simply aggregating the per capita income of the new province with the province that it seceded from. However, while the second problem was being solved, intuitively the first problem was also solved. The second problem is typical for the developing countries where the GDP of provinces or sub-national regions are not calculated. In order to carry on studies that employ sub-national GDP figurers, Henderson, Storeygard and Weil (2012) proposed a readily available proxy, namely, GDP estimations based on Night Time Light (NTL). Authors developed a statistical framework that uses light emissions of a particular geographical region as an indicator of economic activity. The methodology is simple. First, percentage contributions of sub-regions to the total light emission of the country is calculated. Then the national GDP is distributed to these sub-regions according to their percentage contributions. The NTL maps are published by the National Oceanic and Atmospheric Administration's (NOAA) National Geophysical Data Center (NGDC) after processing the raw satellite images. (Henderson \& Storeygard \& Weil, 2012).

By using this proposed technique, Başıhoş (2016), estimated the provincial GDP values of 81 provinces for the period 1992 and 2013 in current dollars. The author concluded that at the national level the correlation between official and estimated data is 0.99938 . Yet, no correlation was calculated at the provincial level. In order to reveal the power of 
estimations, we calculated additional correlation coefficients. On one hand we have the official provincial GDP figures published by TURKSTAT which covers the period 1987 2001, on the other hand we have the estimations which covers the period 1992-2013. Apparently, the period between 1992 and 2001 is covered by both data sets. For most of the provinces $^{3}$, we calculated the correlation between the official and estimated GDP values for the 10 overlapping years. On the average, the correlation coefficient turns out to be 0.963 indicating a strong estimation power. It has been also revealed by these provincial correlations that for those provinces whose territorial land is "normal", the estimated values are close the official statistics. The estimation power of the method decreases for relatively small provinces (i.e. Yalova, Kilis) and for relatively big cities (i.e. Konya, Sivas, Erzurum). The lowest correlation coefficient was captured for Kilis, where the coefficient was 0.8793 . Given the information about the estimations of provincial GDPs, it is safe to conclude that the Night Time Light estimations are well working proxies for the provincial GDPs.

A final remark regarding the data is the categorization of high and low income provinces used in spatial autocorrelation analysis. The classification does not employ a constant, normative per-capita GDP value, instead those provinces whose income is higher than the country wise per-capita GDP of that particular year, are categorized as high income province, and vice versa. This way of categorization enables a floating benchmark per-capita GDP value throughout period which becomes even more crucial in countries, such as Turkey, which experience considerable increase in their per-capita GDPs throughout the period under investigation.

\subsection{Methodology}

The provincial income inequality is measured by employing regional Gini coefficient. While originally it measures the income inequalities among different income groups, Kakwani (1977) have modified the index in order to measure the income inequalities among the regions of an economy. When applied to regional income inequalities, the Gini index may be computed in two methods. The first method (call it unweighted Gini index) does not consider the population, whereas the second method (call it weighted Gini index) computes the Gini index given a set of income values and population weights given in Equations 1 and 2.

$$
\begin{aligned}
G_{u} & =\frac{\sum_{i}^{n} \sum_{j}^{n}\left|y_{i}-y_{j}\right|}{2 y n(n-1)} \\
G_{w} & =\frac{\sum_{i}^{n} \sum_{j}^{n}\left|y_{i}-y_{j}\right| \frac{\left(p_{i} p_{j}\right)}{P^{2}}}{2 y n(n-1)}
\end{aligned}
$$


where; $\mathrm{G}_{\mathrm{u}}$ : Unweighted Gini index, $\mathrm{G}_{\mathrm{w}}$ : Weighted Gini index, $\mathrm{y}$ : national GDP per capita, $\mathrm{y}_{\mathrm{i}}$ : GDP per capita of $\mathrm{i}^{\text {th }}$ region, $\mathrm{n}$ : number of regions, $\mathrm{p}$ : total population, $\mathrm{p}_{\mathrm{i}}$ : population of $\mathrm{i}^{\text {th }}$ region

The unweighted Gini index $\left(G_{u}\right)$ varies from 0 for perfect equality where total income is distributed evenly between regions, to 1 for perfect inequality where only one region gets the whole income. On the contrary the weighted Gini index $\left(G_{w}\right)$ takes the value 0 if regions' income shares are equal to their population shares, and $1-\left(P_{i} / P\right)$ if one region gets whole income. $\left(P_{i} / P\right)$ is the ratio of $i^{\text {th }}$ region's population to total population and if $\mathrm{P}_{\mathrm{i}}$ is small compared to $\mathrm{P}$, (i.e., if the region with a small proportion of the population) produced all of the GDP then the value for perfect inequality would approach 1. (Shankar \& Shah, 2003).

The interdependence or the spatial autocorrelation of regions will be calculated by employing the Moran's I and Moran Scatter-plot (Anselin, 1995). Moran's I is a measure of spatial autocorrelation developed by Patrick A.P. Moran. Like the autocorrelation, spatial autocorrelation means that adjacent observations of the same variable are correlated. However, autocorrelation is about proximity in time whereas spatial autocorrelation is about proximity in (two-dimensional) space. Positive and high level Moran's I means that nearby areas have similar income patterns and indicates global spatial clustering. Whereas, Moran's I will be large and negative when rates are dissimilar.

The Moran's I statistic is expressed as;

$$
I=\frac{n}{s_{0}} \frac{\sum_{i=1}^{n} \sum_{j=1}^{n} w_{i, j} x_{i} x_{j}}{\sum_{i=1}^{n} \sum_{j=1}^{n} x_{i} x_{j}}
$$

where; $x$ is the per capita income of regions in form of deviations from means, wi, $\mathrm{j}$ is an element of a binary spatial weights matrix $\mathrm{W}$ such that if $\mathrm{i}$ and $\mathrm{j}$ are neighbors $w_{i, j}=1$ and $w_{(i, j)}=0$ if not. $x_{i}$ is the natural $\log$ of real per capita income in region $\mathrm{i}$; $\mathrm{n}$ is the number of regions and $s_{0}$ is a scaling factor equal to the sum of all the elements of the matrix W (Rey \& Montouri, 1999).

In the literature, in order to achieve more visualized presentation of spatial autocorrelation Moran scatter-plot is widely used (Anselin, 1995). The graph visualizes the relation between the standardized per capita income and standardized spatial lag of per capita income. The spatial lag of per capita income is calculated by employing the formula below.

$$
\text { Spatial Lag of Per Capita Income }=W_{s} * y
$$

where $\mathrm{W}_{\mathrm{s}}$ is the standardized matrix of nxn binary spatial weights matrix $\mathrm{W}$ (in our case $81 \mathrm{x} 81)$ and $\mathrm{y}$ is the $\mathrm{nx} 1$ vector of per capita incomes $(81 \mathrm{x} 1)$. 
Figure: 1

Moran's Scatterplot

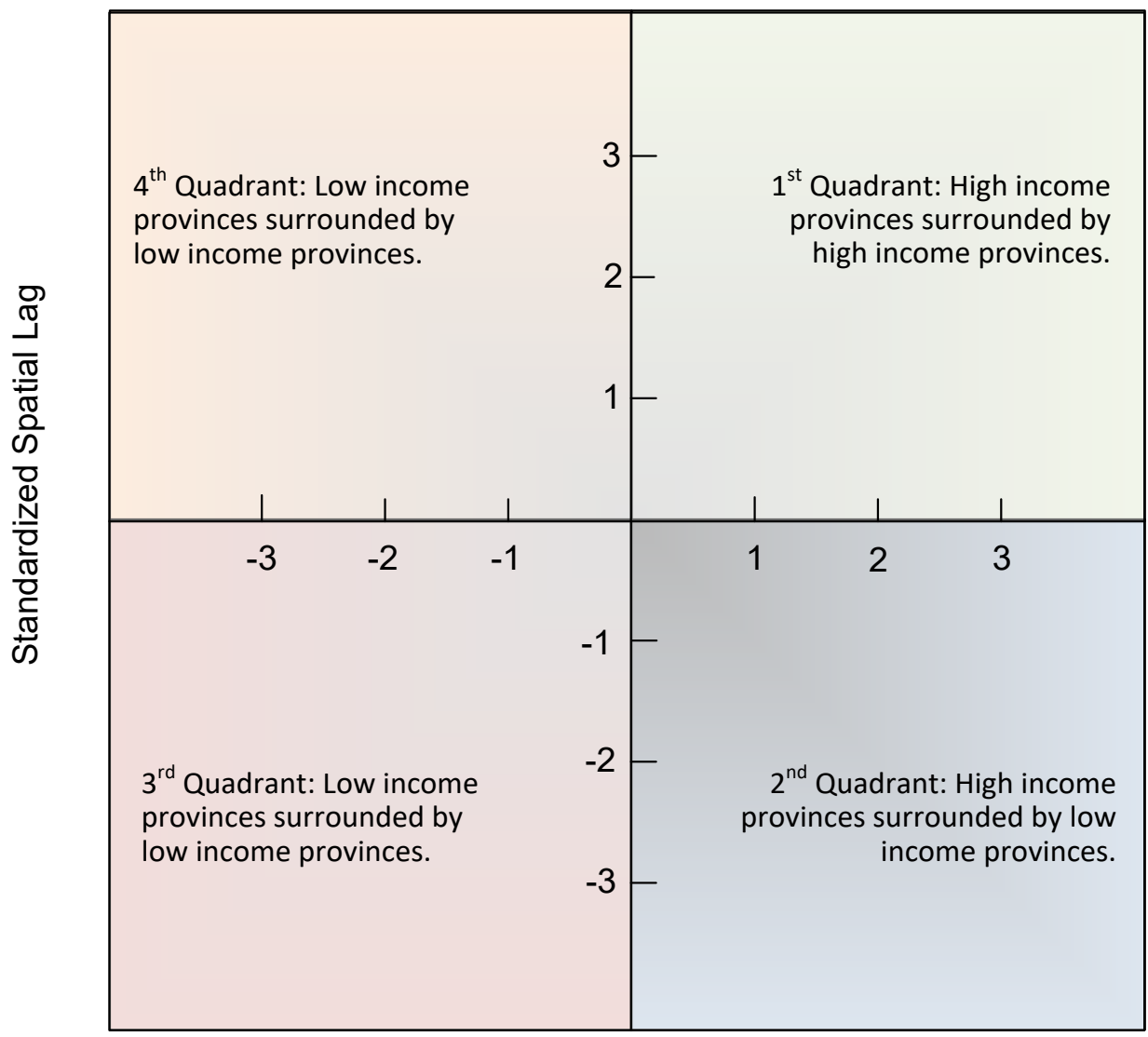

\section{Standardized Per-Capita Income}

In Figure 1 there are four quadrants of the scatter-plot representing different spatial association. The first (upper right), second (lower right), third (lower left) and fourth quadrants (upper left) represent high income provinces with high income neighbors, high income provinces with low income neighbors, low income provinces with low income neighbors and low income provinces with high income neighbors respectively. The first and third quadrants pertain to the positive forms of spatial dependence while the second and fourth quadrant represents negative spatial dependence. The definition of high and low income province depends on whether the provincial income is above or below the country average. 
Plotting these groups of provinces and regions on the map of Turkey for 1992 and 2013 will give us an insight of how income clusters are formed, and will enable us to reveal the economic performances of provinces throughout years under investigation.

\section{Findings}

\subsection{The Gini Coefficient}

Throughout the period under investigation, both the weighted and unweighted Gini show a steady decrease, indicating a recovery in terms of provincial income inequality. Yet, the degree of inequality shows considerable difference between weighted and unweighted measures. The mean of weighted Gini coefficient is 0.073 , whereas the value increases to 0.30 when unweighted Gini is considered. In other words, the level of inequality detected by unweighted Gini coefficient is more than four times of what weighted Gini detected. This is not surprising. The weighted Gini, as explained above, takes population shares of provinces into consideration. If we define low income (high income) provinces according to whether or not the per-capita income of the province is below (above) the mean income, then the high income provinces accounts to $62 \%$ of the total population (50 million inhabitants). Apparently, the income inequality among high income provinces is less than that of low income provinces.

\section{Figure: 2}

\section{The weighted and unweighted Gini coefficients: 1992-2013}
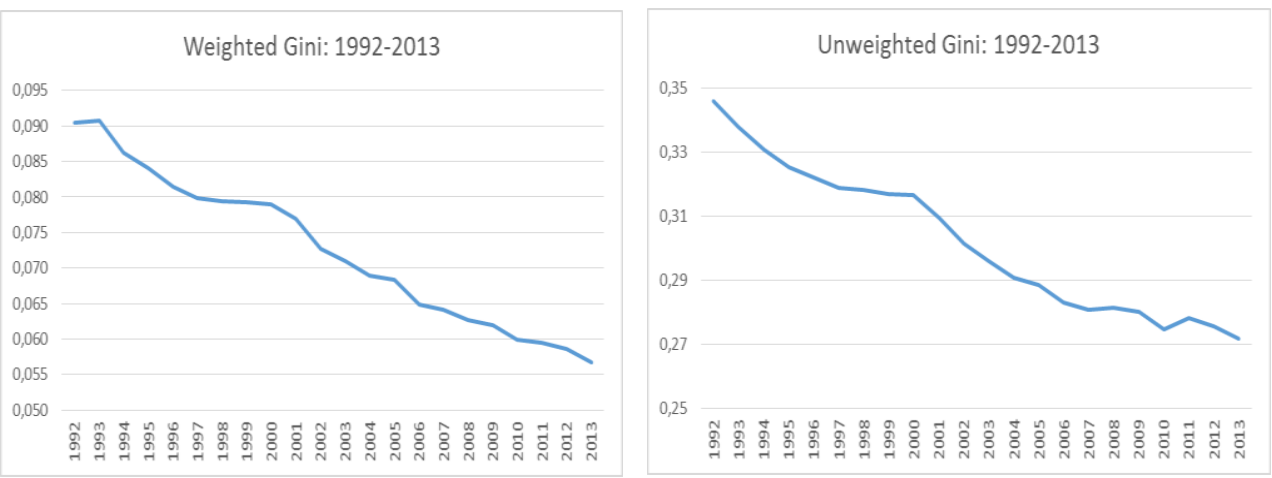

The Gini measure detects some certain amount of income inequality. However, the Gini coefficient has nothing to say about the provincial income clusters. Up until now, we just determined the level of inequality but the spread of high and low income regions are still unknown. These provinces may be distributed randomly across the country or may follow some patterns. Whether the provincial income distribution follows a systematic pattern or not will be investigated by employing (a) global measure of spatial autocorrelation, (b) plotting Moran's scatterplot. 


\subsection{Global Measure of Spatial Autocorrelation (Moran's I)}

The initial level of the global measure of spatial autocorrelation was 0.549 , indicating a very strong relation between provinces' incomes and their neighbors weighted income. If a province is surrounded by high income provinces, then it is easy for that province to be a high income province as well. On the contrary, if on the average, a province is surrounded by low income provinces, then most probably it will remain in the low income category as well. This indicates that the high and low income provinces are not distributed randomly across the country, but instead there are some income clusters and these clusters are very rigid. Throughout the period under investigation, the global measure of spatial autocorrelation is facing a reduction after reaching its peak value of 0.623 in 1995. As of 2013 , the figure has reduced to 0.495 . This reduction in the global measure indicates that the clusters are losing their rigidity. In other words, the spatial interdependence of regions are decreasing over time.

Figure: 3

The Global Measure of Spatial Autocorrelation: 1992-2013

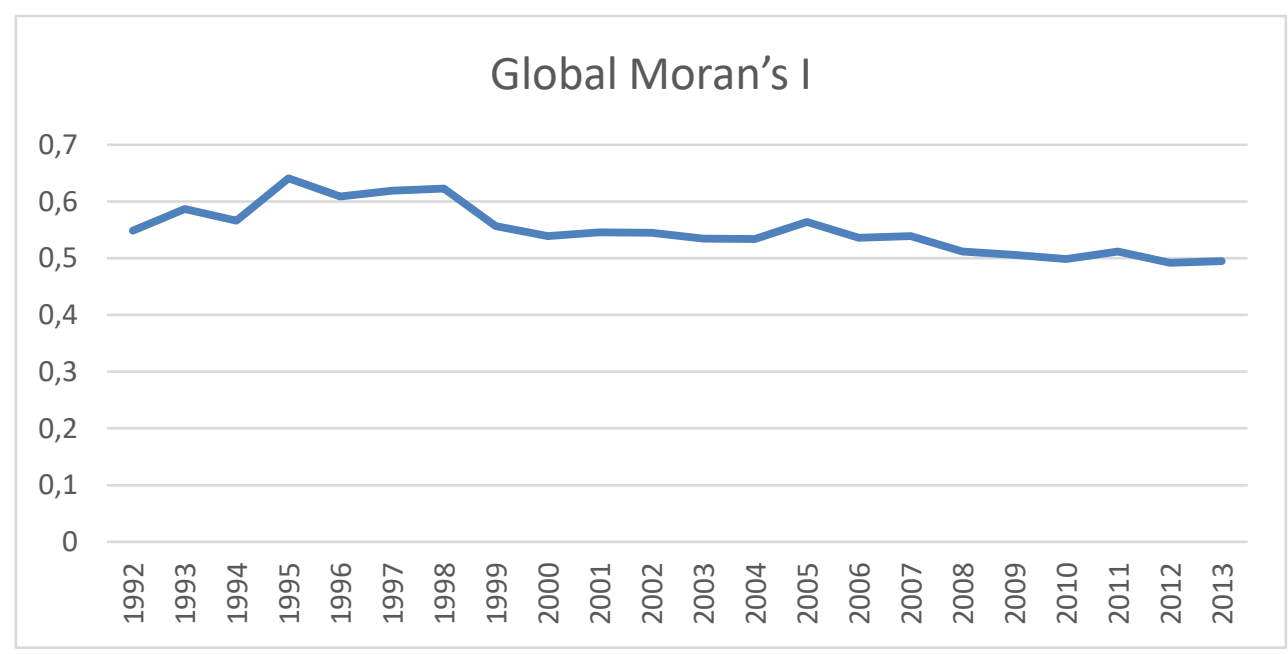

The reduction in global measure of interdependence may have originated from two events; (a) a low income province surrounded by low income provinces may have survived and found itself a place in the league of high income provinces, (b) a high income province surrounded by other high income provinces may have progressed bad and fallen into low income province category. The important point here is that the neighbors income is a weighted average, thus a province at the border between high and low income clusters may have both high income and low income neighbors. Apparently, to shift from high income to low income, or to shift from low income to high income category are much easier for these provinces compared to provinces that are entirely surrounded by either high or low income 
provinces. The reason for the decrease in spatial interdependence will become clear when the provinces are color coded according to their quadrants.

\subsection{Moran's Scatterplot}

In order to visualize the global measure, Moran's scatter plot may be employed. For the sake of simplicity, we have chosen four years; 1992, 1998, 2005 and 2013. In 1992, there are 29 high income and 52 low income provinces. These figures are 31 and 50 in 1998, 35 and 46 in 2005, 38 and 43 in 2013. The change in numbers indicate that the number of high income provinces are gradually increasing over the period under question.

\section{Figure: 4}

\section{Moran's Scatterplot: 1992, 1998, 2005, 2013}
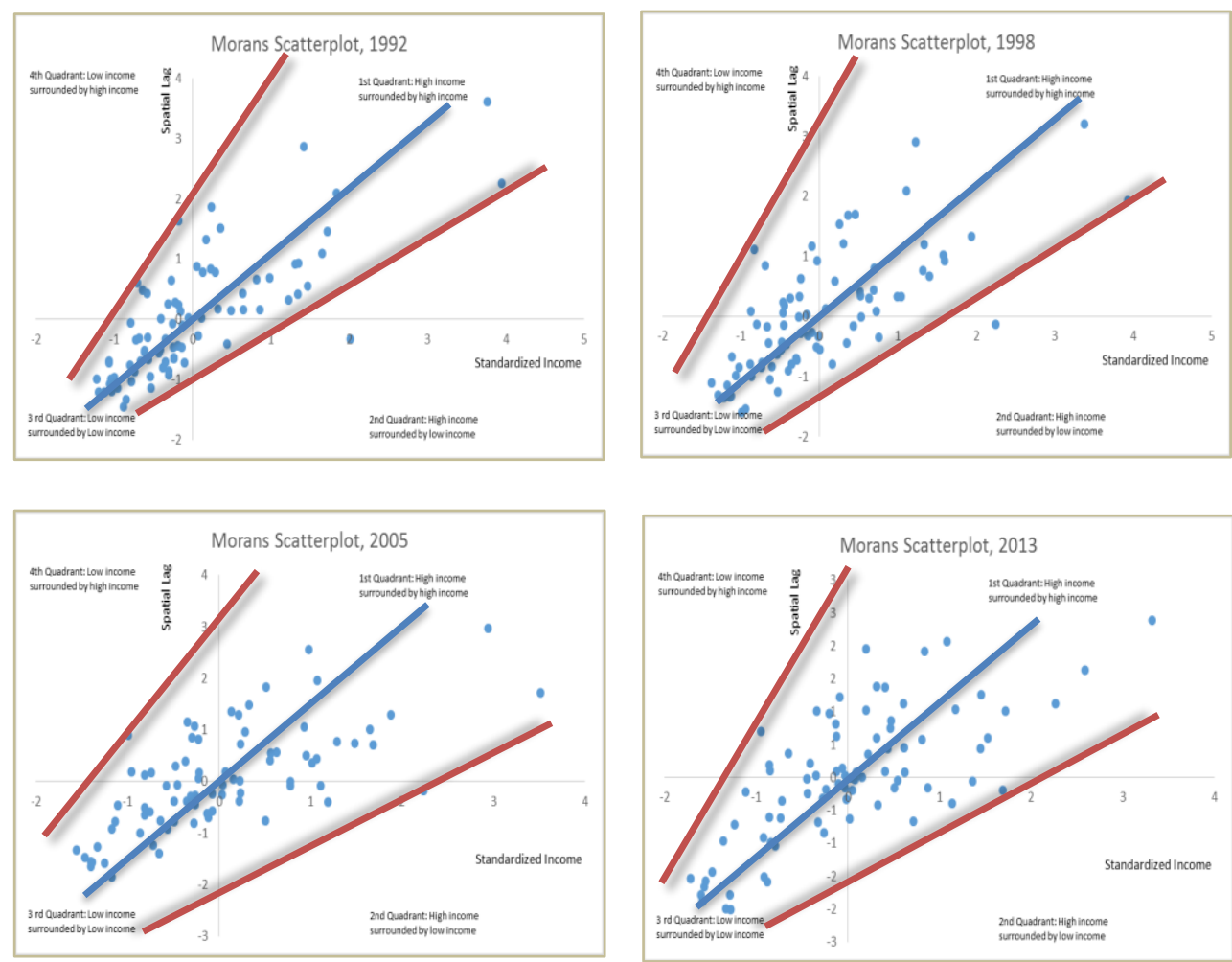

In all the selected year we see that majority of the provinces are either in the first quadrant (high income province surrounded by high income neighbors) or in the third quadrant (low income province surrounded by low income neighbors) For instance in 1992 there are 26 and 41 provinces in the first and third quadrants respectively, where these two quadrants show positive spatial autocorrelation. In the same year there are only three 
provinces in the second quadrant (Kahramanmaraş, Karabük, Kırıkkale) where the high income province is surrounded by low income neighbors. Finally, remaining 11 provinces are low income provinces with high income neighbors. In 2013, 26 and 29 provinces are in first and third quadrants. The number of provinces in the third quadrant has decreased from 41 to 29 in between 1992 and 2013. There are two reasons for that. First some provinces remained low income but since their neighbors sifted to high income they moved to the third quadrant (i.e. Amasya, Aksaray, Niğde) Second, even though their neighbors remained low income, some low income provinces managed to shift themselves to high income category and moved from third quadrant to the second quadrant (i.e. Artvin, Rize, Trabzon, Ordu, Tokat, Malatya).

Analyzing the evolution of Moran's scatterplot (Figure 4) reveals that in 1992 the distribution of provinces across quadrants are denser. In other words, the spread of provinces around perfect spatial autocorrelation line more dense in 1992 compared to 2013 indicating that spatial interdependence is decreasing throughout period of analysis. This result is consistent with the findings of the global measure of spatial autocorrelation.

Figure: 5

\section{Color Coding Turkish Provincial Map According to Moran’s Scatterplot}
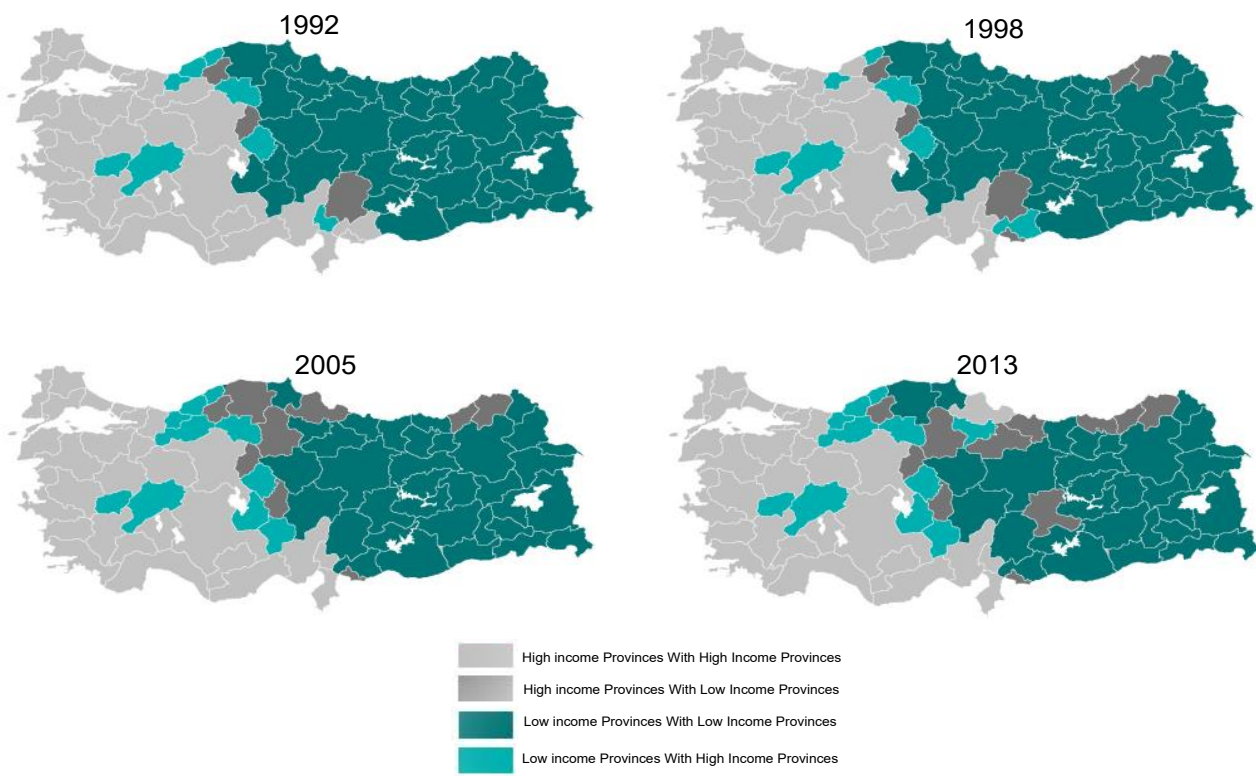

Color coding provinces according to quadrant they belong reveals interesting results. Up until now we verified that low and high income provinces are highly clustered. Color coding reveals that high income provinces are clustered in the west and low income province are clustered in the east. A hypothetical line roughly drawn from Bartin to Hatay sets the 
border between high income and low income provinces. The provinces at the second and fourth quadrant of the Moran's scatter plot are usually provinces close to this hypothetical border. Two provinces (Afyon and Uşak) are deep in high income cluster, but throughout the period, they could not manage to shift from low income category to high income category. Thus we may argue that spatial interdependence for these provinces are low. On the other side of the map there are also some provinces (Samsun, Artvin, Trabzon Rize and Malatya) where the spatial interdependence are low. These provinces were surrounded entirely by low income provinces in 1992 yet they managed to move to high income category. Apparently this shift from low income to high income category stimulated some of the surrounding provinces as well. For instance, after Samsun shifting from low income to high income category in 2005, its neighbor Amasya also shifted to high income category in 2013 .

The only province that was in the first quadrant in 1992 that moved to fourth quadrant is Bolu. The province was surrounded by high income provinces however it turned out low income province as of 2013.

\subsection{A Remark on Results}

As stated earlier, the definition of high (low) income provinces depends on whether the per-capita income of the province is above (below) the country average. This definition leads to a practical problem. Regardless of the per-capita income level, some provinces will always be in low income category. In other words, since there is no unique, pre-determined per-capita GDP level, the definition of high and low income provinces dictates that it is impossible for all provinces to be in high income category.

At first glance, the reduction in the number of low income provinces may seem to be an affirmative result. However, under the light of the above definition, one should also be aware that the reduction in low income provinces also indicates that those provinces remained in low income category are now in even more desperate situation. Initially, poverty was distributed among 52 provinces (total of provinces in the third and fourth quadrant of the Moran's scatterplot) but in 2013 this number reduced to 43. Even though the distribution of high and low income provinces across the country became more random, we may assume that the poverty is now more concentrated in low income provinces.

\section{Conclusion}

Growth and distribution are two distinct issues within the context of macroeconomics. Turkey's progress in terms of growth is at conceivable rates, however, income distribution either among income groups or provinces still remain to be problematic. This paper investigated (a) level of provincial income inequality, (b) whether high and low income provinces are distributed randomly or follows some clusters.

The first goal is achieved by employing weighted and unweighted Gini coefficients and both measures detected a decrease in provincial income inequality. The inequality 
detected by weighted Gini coefficient is lower than that of the unweighted Gini coefficient. The reason for the difference between the levels of inequality detected by two measures is the fact that the weighted Gini considers population shares as well and since the high income provinces are usually those provinces with considerable amount of population, at the country level, the coefficient detects a lower inequality.

The second goal follows a step by step procedure. First the global measure of interdependence for each year is calculated by employing spatial autocorrelation measure developed by Moran. Results reveal that the spatial interdependence between provinces has decreased over the period under investigation. Yet, the recent level still indicates a highly clustered distribution of low and high income provinces. The second step is to visualize the global measure by employing Moran's scatterplot. Graphs indicate a high positive spatial autocorrelation. One may argue that if a high (low) province is surrounded by other high (low) income provinces, then it is hard for that province to move to low (high) income province category.

The final step is to color code the provinces according to the quadrants they belong in Moran's scatterplot. For the four selected years (1992, 1998, 2005, 2013), maps reveals the fact that the high and low income provinces are clustered, and that the high income cluster is at the west and the low income cluster is at the east. This result actually just reveals what is already known. However, deeper analysis indicates that swing provinces (either from high income to low income or from low income to high income) are often at the border between the clusters. There are only couple of exceptions of this fact (Afyon, Uşak, Artvin, Rize and Trabzon). The one sentence summary of the study is that, a hypothetical line between Ereğli and Hatay roughly defines the border between high and low income provinces.

\section{References}

Akgüngör, S. (2003), Exploring regional specializations in Turkey's manufacturing industry, Regional Studies Association International.

Anselin, L. (1995), "Local Indicators of Spatial Association - LISA”, Geographical Analysis, 27, 93115.

Anselin, L. (2013), Spatial Econometrics: Methods and Models, Springer Science and Business Media.

Barro, R.J. \& X. Sala-i Martin (1992), “Convergence”, Journal of Political Economy, 100(2), 223251.

Başıhoş, S. (2016), “Gelişmişlik Göstergesi Olarak Gece Işıkları: Ulusal Ölçekte ve İl Bazında GSYH Tahmini”, Tepav Tartışma Metni, <http://www.tepav.org.tr/tr/haberler/s/4052>, 23.08.2017.

Başlevent, C. \& M. Dayığlu (2005), “A household level examination of regional income disparity in Turkey", METU Studies in Development, 32(2), 275-288.

DeJuan, J. \& M. Tomljanovich (2005), "Income convergence across Canadian provinces in the 20th century: Almost but not quite there", The Annals of Regional Science, 39(3), 567-592. 
Dinler, Z. (2005), Bölgesel İktisat: Genel Olarak Türkiye'de Bölgeler Arası Gelişmişlik Farklılıklarının Ortaya Çıkışı ve Azaltılmasına Yönelik Politikalar, Bursa: Etkin Kitabevi.

Erk, N. \& S. Ateş \& T. Direkçi (2000), "Convergence and Growth within GAP Region (South Eastern Anatolia Project) and Overall Turkey's Regions", IV. ODTÜ Uluslararast Ekonomi Kongresi, 13-16.

Falk, R. (1999), Predatory Globalization: A Critique, Malden: Blackwell Publishers.

Henderson, J.V. \& A. Storeygard \& D.N. Weil (2012), "Measuring Economic Growth From Outer Space", American Economic Review, 102(2), 994-1028.

Kakwani, N.C. (1977), “Applications of Lorenz curves in economic analysis”, Econometrica: Journal of the Econometric Society, 45(3), 719-727.

Karaca, O. (2004), “Türkiye'de Bölgeler Arası Gelir Farklılıkları: Yakınsama Var mı?”, Türkiye Ekonomi Kurumu Discussion Paper No:2004/7.

Kuznets, S. (1955), "Economic Growth and Income Inequality", American Economic Review, 45(1), $1-28$.

Milanovic, B. (1997), "A simple way to calculate the Gini coefficient, and some implications", Economic Letters, 56(1), 45-49.

Öztürk, L. (2005), “Bölgelerarası Gelir Eşitsizliği: İstatistiki Bölge Birimleri Sınıflandırması'na (İBBS) Göre Eşitsizlik İndeksleri ile Bir Analiz, 1965-2001”, Akdeniz University Faculty of Economics and Administrative Sciences Faculty Journal, 5(10), 95-110.

Rey, S.J. \& B.D. Montouri (1999), "US regional income convergence: a spatial econometric perspective", Regional Studies, 33(2), 143-156.

Rodrick, D. (1997), Has globalization gone too far?, Institute for Unternational Economics.

Shankar, R. \& A. Shah (2003), "Bridging the economic divide within countries: A scorecard on the performance of regional policies in reducing regional income disparities", World Development, 31(8), 1421-1441. 
Uslu, Ç.L. (2017), "Provincial Income Inequality and Spatial Autocorrelation Across Turkish Provinces: 1992-2013”, Sosyoekonomi, Vol. 25(34), 197-211. 